\title{
CYP19A1 Gene
}

National Cancer Institute

\section{Source}

National Cancer Institute. CYP19A1 Gene. NCI Thesaurus. Code C26501.

This gene is involved in development and estrogen metabolism. 